\title{
Design of Bio Gas Generation Plant Based on Food Waste
}

\author{
Rajendra Beedu ${ }^{\dot{\mathrm{A}}^{*}}$ and Pratik Modi ${ }^{\dot{\AA}}$ \\ ${ }^{\dot{A}}$ Department of Mechanical and Manufacturing Engineering, Manipal Institute of Technology, Manipal University, Manipal, Karnataka, India
}

Accepted 10 January 2014, Available online 01 February 2014, Special Issue-2, (February 2014)

\begin{abstract}
This paper deals with the design and fabrication of a food waste based biogas generation system. An experimental setup is designed and implemented and the paper illustrates the working principle, chemical analysis, cost effectiveness of biogas plant compared to Liquid Petroleum Gas. Also the paper explains the method of transportation of waste food from different locations to multiple biogas plants.
\end{abstract}

Keywords: Biogas, Food Waste, Bacteria, Chemical analysis, LPG

\section{Introduction}

Most of the families in India depend on L P G for cooking and the demand is increasing day by day. We have to spend a large amount of foreign exchange for importing crude oil. Also, in a densely populated nation like India, disposal of waste food, creates the problem of environmental decay and hence needed to be handled properly. Gobar gas plants developed in 80's were not effective because they could be implemented in villages. In addition, gobar gas plants are not effective due to less heat generation (Robert Jon Lichtman, 1983). Biogas plant can be easily implemented in urban or rural areas where waste food with high starch content is available which can be used to produce methane gas and remaining slurry can be used as manure (K. R. Smith, 2001). If $20 \%$ of L P G is replaced by waste food based bio gas plant, it will lead to a saving of substantial amount of foreign exchange and improve the economy of the nation. Also atmospheric degradation can be minimized.

\section{Process of Producing Biogas}

The process of producing biogas involves anaerobic digestion. In this process, acetic acid forming bacteria (acetogens) and methane forming archea (methanogens) are fed to the digester. The oxygen source in an anaerobic system is derived from the organic material itself. In the presence of specialized methanogens, the intermediates are converted to the 'final' end products of methane, carbon dioxide, and trace levels of hydrogen sulfide. In an anaerobic system, the majority of the chemical energy contained within the starting material is released by methanogenic bacteria as methane. Populations of anaerobic microorganisms typically take a significant period of time to establish themselves to be fully effective.

*Corresponding author: Rajendra Beedu

DOI: http://dx.doi.org/10.14741/ijcet/spl.2.2014.77
Therefore, common practice is to introduce anaerobic microorganisms from materials with existing populations, a process known as seeding the digesters, typically accomplished with the addition of sewage sludge or cattle slurry (Dhakal NR, 2003).

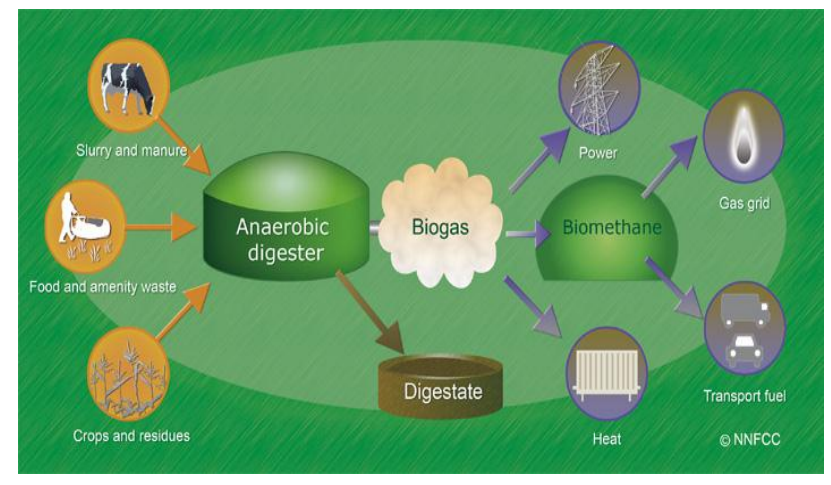

Fig 1 Anaerobic Digestion

\section{Design}

The dimension of biogas plant depends on the thermal energy to be produced. Since it is intended to replace a part of L P G gas, the energy equivalent for 1 cylinder of LPG is calculated.

Equivalence with LPG

Calorific value of $\mathrm{LPG}=50 \mathrm{MJ} / \mathrm{kg}$

One cylinder weighs $14.2 \mathrm{~kg}$

Therefore, net energy in 1 cylinder $=14.2$ x $50 \mathrm{MJ}$

The net energy in 1 cylinder $=710 \mathrm{MJ}$

The energy available in $1 \mathrm{~m} 3$ plant in one month.

Biogas contains about $60 \%$ methane.

Calorific Value of methane $=55 \mathrm{MJ} / \mathrm{kg}$

Density of Methane at NTP $=0.668 \mathrm{~kg} / \mathrm{m} 3$ 
Therefore, Calorific value of methane $=55 \times 0.668$

$$
=36.74 \mathrm{MJ} / \mathrm{m} 3
$$

Methane being the only major source of heat,

Calorific value of biogas $=0.6 \times 36.74 \mathrm{MJ} / \mathrm{m} 3$

$$
=22.044 \mathrm{MJ} / \mathrm{m} 3
$$

A plant of $1 \mathrm{~m} 3$ capacity produces $0.7 \mathrm{~m} 3$ of gas per day.

Net energy in $0.7 \mathrm{~m} 3$ of biogas $=0.7 \times 22 \mathrm{MJ}$

Net energy in $0.7 \mathrm{~m} 3$ of biogas $=15.4 \mathrm{MJ}$

Assuming that the efficiency of a biogas stove and LPG stove is the same

Energy provided per month $=15.4 \times 30$

Energy provided per month $=462 \mathrm{MJ}$

Therefore a biogas plant of $1 \mathrm{~m} 3$ capacity is equivalent to $65 \%$ of an LPG cylinder per month.

\section{Fabrication of biogas plant:}

From the literature review, it is found that Arti- Biogas plant system with proper modifications is efficient in producing biogas for cooking purpose.

The design consists of the assembly of two high density polythene (HDPE) tanks of 1 and $0.75 \mathrm{~m} 3$ capacity assembled with proper fittings. Smaller tank is the biogas collector which is connected to a burner through a pipe line. The two tanks are fitted with proper sealing. To increase the surface area for the development of biofilms, pebbles of stone is filled at the bottom of lower tank. Also, to provide more surface area plastic mosquito net filled with plastic waste is fitted in the digester in the vertical position as shown in Fig 2. The plant is ready for use.

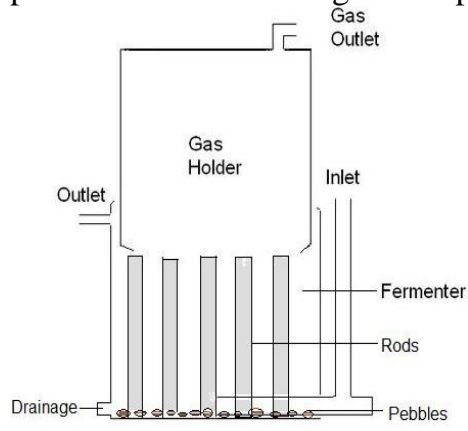

Fig 2 Elevation of Cut section of the plant

\section{Working}

About $80 \mathrm{~kg}$ of wet cow dung was mixed uniformly in batches of $10 \mathrm{~kg}$ in 15 litres of water to create a consistent mixture. This was poured into the digester tank which was then filled with water till water reached the overflow mark. The gas chamber is mounted on the digester. The tank is left undisturbed for 5 days. The gas burner is ignited and blue flame of methane is observed. Now the digester is ready to receive food waste.

\section{Testing}

The testing involves the measurement of volume of biogas produced under the following conditions. a) Varying feed (0.25 to $2.25 \mathrm{~kg}$ in 9 days)

b) Feeding constant amount in different intervals of time (1 day to 5 days)

c) Different types of feed (dumped, crushed or blended)

d) Feeding irregular amount with breaks in the supply ( 0.2 to $2 \mathrm{~kg}$ )

e) Regular underfeeding of $0.75 \mathrm{~kg} / \mathrm{day}$

The volume is approximately $0.8 \mathrm{x}$ height of gas holder in metres (truncated to lower value in $2^{\text {nd }}$ decimal).

Table 1 Volume of gas due to varying feed

\begin{tabular}{|l|l|l|l|}
\hline Day & Mass of Feed $(\mathrm{kg})$ & $\begin{array}{l}\text { Height of Tank } \\
\text { above digester } \\
\text { liquid level }(\mathrm{m})\end{array}$ & $\begin{array}{l}\text { Volume of } \\
\text { Gas }\left(\mathrm{m}^{3}\right)\end{array}$ \\
\hline 1 & 0.25 & 0.13 & 0.1 \\
\hline 2 & 0.5 & 0.19 & 0.15 \\
\hline 3 & 0.75 & 0.32 & 0.25 \\
\hline 4 & 1.0 & 0.48 & 0.38 \\
\hline 5 & 1.25 & 0.63 & 0.5 \\
\hline 6 & 1.5 & 0.75 & 0.6 \\
\hline 7 & 1.75 & 0.82 & 0.65 \\
\hline 8 & 2.0 & 0.86 & 0.68 \\
\hline 9 & 2.25 & 0.86 & 0.68 \\
\hline
\end{tabular}

Volume of Gas

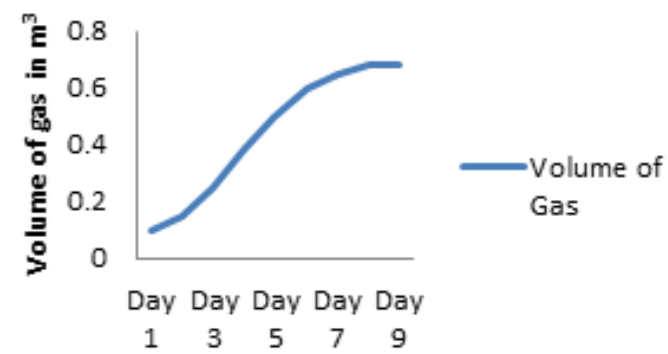

Fig 3 Graph showing change in volume of gas due to varying feed

Table 2 Change in Volume of gas after different periods without feed

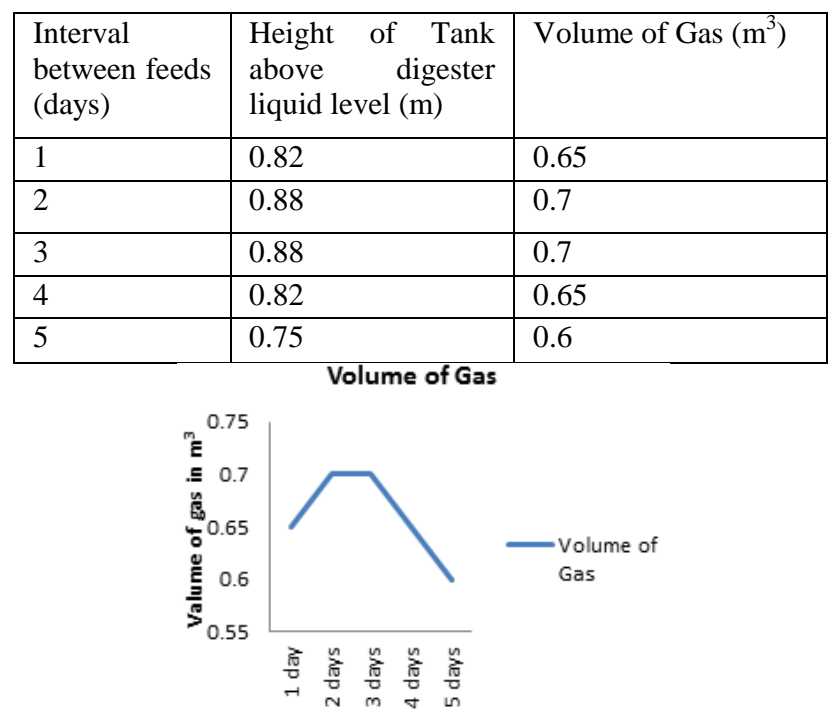

Fig 4 Change in Volume of gas after different periods without feed. 
Table 3: Volume of gas due to different nature of feed

\begin{tabular}{|l|l|l|}
\hline Nature of Feed & $\begin{array}{l}\text { Height of Tank } \\
\text { above digester } \\
\text { liquid level }(\mathrm{m})\end{array}$ & $\begin{array}{l}\text { Volume of Gas } \\
\left(\mathrm{m}^{3}\right)\end{array}$ \\
\hline Whole & 0.30 & 0.24 \\
\hline Crushed & 0.63 & 0.5 \\
\hline Blended & 0.82 & 0.65 \\
\hline
\end{tabular}

\section{Volume of Gas}

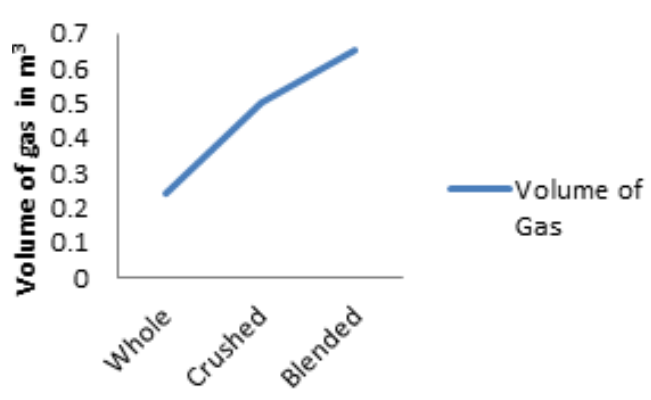

Fig 5 Volume of gas due to different nature of feed.

Table 4 Volume of gas $/ \mathrm{kg}$ of feed due to irregular feeding

\begin{tabular}{|l|l|l|l|l|}
\hline Day & $\begin{array}{l}\text { Mass of } \\
\text { Feed (kg) }\end{array}$ & $\begin{array}{l}\text { Height of } \\
\text { Tank above } \\
\text { digester liquid } \\
\text { level (m) }\end{array}$ & $\begin{array}{l}\text { Volume of } \\
\text { Gas }\left(\mathrm{m}^{3}\right)\end{array}$ & $\begin{array}{l}\text { Volume per } \\
\mathrm{kg} \text { of feed } \\
\left(\mathrm{m}^{3} / \mathrm{kg}\right)\end{array}$ \\
\hline 1 & 2 & 0.88 & 0.7 & 0.35 \\
\hline 2 & 1.2 & 0.50 & 0.4 & 0.33 \\
\hline 3 & 0 & 0.06 & 0.05 & - \\
\hline 4 & 0.7 & 0.28 & 0.22 & 0.31 \\
\hline 5 & 0 & 0.06 & 0.05 & - \\
\hline 6 & 0.2 & 0.08 & 0.06 & 0.3 \\
\hline 7 & 0 & 0 & 0 & - \\
\hline 8 & 2.2 & 0.76 & 0.6 & 0.27 \\
\hline 9 & 1 & 0.31 & 0.25 & 0.25 \\
\hline 10 & 2 & 0.70 & 0.55 & 0.27 \\
\hline
\end{tabular}

Volume of gas $/ \mathrm{kg}$ of feed

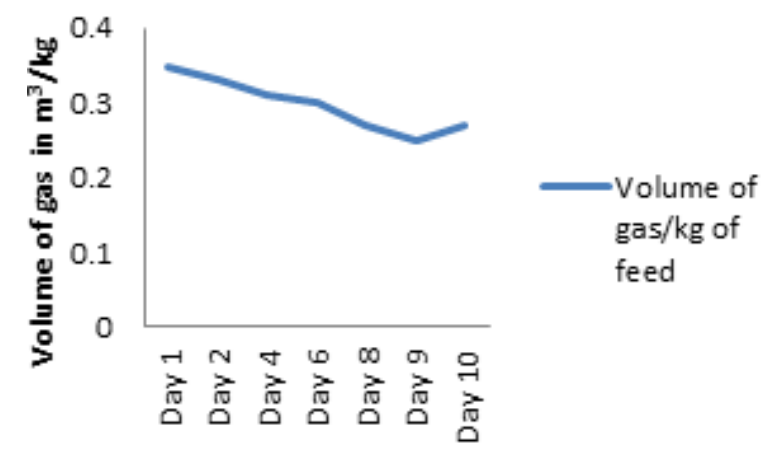

Fig 6 Volume of gas $/ \mathrm{kg}$ of feed due to irregular feeding Table 5 Effect of regular underfeeding on volume of gas

\begin{tabular}{|l|l|l|}
\hline Day & $\begin{array}{l}\text { Height of Tank above } \\
\text { digester liquid level (m) }\end{array}$ & Volume of Gas $\left(\mathrm{m}^{3}\right)$ \\
\hline 1 & 0.34 & 0.25 \\
\hline 2 & 0.34 & 0.25 \\
\hline 3 & 0.32 & 0.25 \\
\hline 4 & 0.34 & 0.27 \\
\hline 5 & 0.34 & 0.27 \\
\hline
\end{tabular}

\begin{tabular}{|l|l|l|}
\hline 6 & 0.32 & 0.25 \\
\hline 7 & 0.34 & 0.27 \\
\hline 8 & 0.32 & 0.25 \\
\hline 9 & 0.30 & 0.24 \\
\hline 10 & 0.30 & 0.24 \\
\hline 11 & 0.30 & 0.24 \\
\hline 12 & 0.28 & 0.22 \\
\hline 13 & 0.26 & 0.21 \\
\hline 14 & 0.25 & 0.20 \\
\hline
\end{tabular}

Volume of Gas

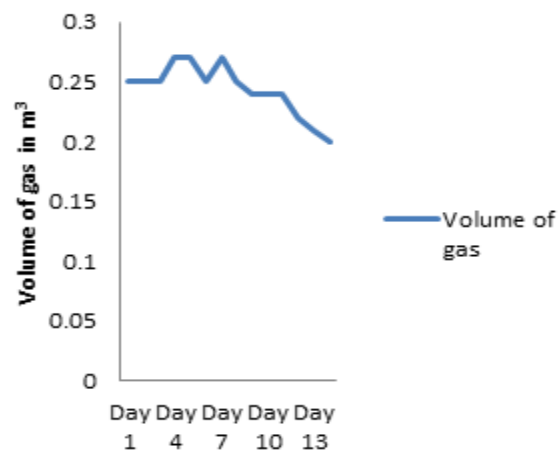

Fig 7 Effect of regular underfeeding on volume of gas

\section{Observation}

a) In Fig 3 , the increase in gas production per unit mass of feed from the $5^{\text {th }}$ day onwards can be attributed to the effects of a more settled bacteria culture due to increase in feed, the digestion of any undigested waste due to compounding since the reaction takes between 24 and 36 hours to complete and due to improper mixing in the digester.

b) In Fig 4, a significant drop after not feeding for 5 days was observed. This shows that the plant can go without being fed for 3- 4 days without significant loss in performance.

c) In Fig 5, it is clear that feeding the plant with whole food results in large under utilization of the plant as it takes much longer to digest. Hand crushed food works good with foods that can be crushed down to paste by hand but foods like chapattis show a significant drop in volume of gas generated unless they are blended using a blender.

d) In Fig 6, a noticeable dip in the amount of gas generated per unit mass of feed is observed. The bacteria culture is negatively affected due to irregular feed and missed feed.

e) A consistent drop in production is observed from the $8^{\text {th }}$ day of underfeeding (Fig 7). The gas production dropped to a minimum of $0.2 \mathrm{~m}^{3}$ from the regular 0.25 $\mathrm{m}^{3}$ in a period of 14 days.

Feasibility study for implementing the project in Manipal Junior College:

Manipal Junior College, Manipal prepares meals for 250 students and regular canteen food is prepared as well. The school buys about 4 cylinders per month which are used only for preparing the mid-day meal.

4 cylinders of $\mathrm{LPG}=4 \times 710 \mathrm{MJ}$

419 | International Conference on Advances in Mechanical Sciences 2014 


$$
=2840 \mathrm{MJ}
$$

Energy required per day $=2840 / 24 \mathrm{MJ}$

$$
=118.33 \mathrm{MJ}
$$

Energy obtained per cubic metre of biogas $=22 \mathrm{MJ}$

Gas requirement to supplement $50 \%$ of gas use $=118.33 \mathrm{x}$ $0.5 / 22 \mathrm{~m}^{3}=2.7 \mathrm{~m}^{3}$

Therefore required size of digester $=2.7 / 0.7 \mathrm{~m}^{3}$

$$
=3.85 \mathrm{~m}^{3}
$$

Therefore $4 \mathrm{~m}^{3}$ digester and $3 \mathrm{~m}^{3}$ gas collector should provide $50 \%$ of the energy requirements.

\section{Cost Analysis:}

\section{ARTI design:}

The ARTI design using HDPE tanks would cost Rs. 4000 x 7 + Rs. $2000=$ Rs. 30000 approximately since the cost of HDPE tanks is about Rs. 4000 per $\mathrm{m}^{3}$.

Cost of $14.2 \mathrm{~kg}$ cylinder of HP LPG as on $25^{\text {th }}$ May 2012 is Rs. 450.

Expenditure on LPG per year $=4 \times 450 \times 10$

$$
=\text { Rs. } 18,000
$$

Savings up to $50 \%$ a year result in saving of Rs. 9000 per year.

Therefore, payback period $=30,000 / 9,000$

$$
=3.33 \text { years when considering only gas }
$$

usage.

Cost of liquid fertilizer $=$ Rs. 10 per 30 litres.

Therefore benefit due to fertilizer $=10 \times 24 \times 10$

$$
=\text { Rs. } 2400 \text { per year. }
$$

Total savings per year $=$ Rs. $9000+$ Rs. 2400

$$
=\text { Rs } 11,400
$$

Payback period $=30,000 / 11,400$

$$
=2.6 \text { years }
$$

\section{Food Waste Distribution}

Instead of considering left out food as wastage, now food waste may be considered as a source of energy. As a result, the food waste gains market and its distribution should be made economical. Manipal food court on an average generates about $800-900 \mathrm{kgs}$ of food waste.

\section{Conclusions}

Food waste is a very good substitute for L P G gas because India is self-reliant in food production and crude oil is imported.

A regular feeding of biogas plant with proper amount will ensure consistent release of biogas and ensures uninterrupted production of gas.

Even if the plant is not fed for one or two days, (Saturday and Sunday in a school), the efficiency of the plant is not affected.
Crushed and blended food improves the liberation of biogas as digestion becomes easy.

Underfeeding or overfeeding of plant should be avoided. Underfeeding keeps the plant inefficient and overfeeding increases the $\mathrm{Ph}$ value of food waste and reduces the development of microbes.

The payback period is small. Hence affordable in schools and small canteens.

The local distribution system in any small location between plants and hotels ensures continuous supply of food waste with an added advantage of reduction in environmental hazards.

Food provided under mid-day meal is simple and mostly rice so a simple single stage digestion process is sufficient and effective.

Schools have ownership and complete stake in the plants hence are more responsible for its working as was seen in household level plants.

\section{References}

Harka Man Lungkhimba, Amrit Bahadur Karki and Jagan Nath Shrestha (2010), Biogas Production from Anaerobic Digestion of Biodegradable Household Wastes, Nepal Journal of Science and Technology 11 167-172 167

Dhakal, N.R. (October 12-14, 2003), Use of vegetable and kitchen wastes as alternative feed stocks for biogas production. In: Proceedings of international conference on renewable energy technology for rural development. Kathmandu (Eds. J.N. Shrestha, T.R. Bajracharya, B. Vaidya \& S. Pradhan). Centre for Energy Studies, Institute of Engineering, Kathmandu, Pp. 114-121.

M. Kaltschmitt, D. Thrän and K. R. Smith, (Academic Press, 2001), Renewable Energy from Biomass, in Encyclopedia of Physical Science and Technology, ed. by R. A. Meyers ,Pp. 203-228

Raymond Myles, (November 19-21, 2001) Implementation Of Household Biogas Plant by NGOs in India, Practical Experience in Implementation Household Biogas Technology, Lessons Learned, Key Issues And Future Approach For Sustainable Village Development In: VODO International Conference on Globalisation and Sustainable Development, at Antwerp, Brussels, sponsored by Belgian Government, the Flemish Federation of Third-World Organizations and VODO (Vlaams Overleg Duurzame Ontwikkeling Flemish Network on Sustainable Development), Belgium. Page 12

Biogas Digest Volume II, Biogas - Application and Product Development Information and Advisory Service on Appropriate Technology

Robert Jon Lichtman (1983), Biogas Systems in India, VITA/COSTED, ISBN O-86619-167-4

Handbook of Biogas Utilization (February 1988), U.S. Department of Energy. 